\title{
Tindak Pidana Penganiayaan dalam Fiqh Jinayah dan Hukum Pidana Indonesia
}

\author{
Eko Wahyudi \\ VIN Sunan Ampel Surabaya| eko_w2004@gmail.com
}

\begin{abstract}
Often the violence perpetrated by a group of people against suspected perpetrators of certain acts of crime, sometimes even people doing things that are beyond the boundaries of humanity, called "citizen vigilantism". This paper is a description of the persecution in fiqh jinayah and positive criminal law. The conclusion of this paper is that in fiqh jinayah persecution consists of (1) due to deliberate and (2) due to negligence, whose object consists of: (1) regarding parts of the human body, (2) removes the meaning of limbs, wounds on the head, (4) injuries to other limbs, and (5) other injuries, while the punishment is qișas, if forgiven then replaced diyah, and if forgiven then replaced ta'zir. Whereas in the Indonesian Penal Code, persecution consists of due to "deliberate" or "negligence", which is divided into (1) ordinary abuse, (2) minor persecution, (3) plain old-planned persecution, (4) severe persecution and (5) persecution weight with a planned first.
\end{abstract}

Abstrak: Sering kekerasan yang dilakukan sekelompok masyarakat terhadap orang-orang yang diduga sebagai pelaku tindak kejahatan tertentu, bahkan terkadang masyarakat melakukan hal-hal yang sifatnya di luar batas kemanusiaan, yang disebut "vigilantisme citizen". Tulisan ini merupakan deskripsi atas penganiaayaan dalam fiqh jināyah dan hukum pidana positif. Kesimpulan dari tulisan ini adalah, bahwa dalam fiqh jinayah penganiayaan terdiri dari (1) dikarenakan disengaja dan (2) dikarenakan kesalahan, yang obyeknya terdiri dari: (1) mengenai bagian anggota tubuh manusia, (2) menghilangkan makna anggota tubuh, (3) luka di kepala, (4) luka pada anggota badan yang lain, dan (5)luka selain itu. Sedangkan hukumannya adalah qișaș, jika dimaafkan maka diganti diyah, dan jika dimaafkan maka diganti ta'zir. Sedangkan dalam Hukum Pidana Indonesia, penganiayaan terdiri dari dikarenakan karena kesengajaan atau kealpaan, yang terbagi pada (1)

Al-Qānūn, Vol. 20, No. 1, Juni 2017 
penganiayaan biasa, (2) penganiayaan ringan, (3) penganiayaan biasa yang direncanakan lebih dahulu, (4) penganiayaan berat dan (5) penganiayaan berat dengan direncanakan lebih dahulu.

Kata kunci: penganiayaan, fiqh jinayah, hokum pidana Indonesia

\section{A. Pendahuluan}

Hukum merupakan pencerminan dari keadaan masyarakat, tumbuh dan timbulkannya dari kesadaran masyarakat, sehingga hukum itu tak dapat di lepaskan dari sifat suatu bangsa. Selain itu, hukum berguna untuk menyalurkan kehendak masyarakat menuju realisasi citacita masyarakat. Jadi hukum berpengaruh terhadap masyarakat dan masyarakat berpengaruh pula terhadap hukum. ${ }^{1}$

Demi ketertiban, kebahagiaan, dan keselamatan masyarakat itulah hukum mutlak di butuhkan. Untuk itu perlu adanya alat-alat dan subjek-subjek yang menegakkan. Di dalam masyarakat umumnya telah ada petugas-petugas penegak dan pelaksana hukum pidana formil yang khusus di beri wewenang-wewenang dan kekuasaan-kekuasaan tertentu oleh negara, misalnya : polisi, jaksa, hakim dan lain sebagainya. Sedang hukum pidana materiil yaitu hukum yang tercantum dalam KHUP, yang berhak menentukan adalah pemerintah.

Bagaimana jika subjek-subjek penegak (polisi, jaksa, hakim) di lampau oleh masyarakat itu sendiri, artinya masyarakat "berperan"2 sebagai polisi, jaksa dan hakim sekaligus. Misal menghakimi orang-orang yang di duga sebagai pelaku tindak pidana kejahatan; mengkroyok

${ }_{1}^{1}$ Samidjo, Pengantar Hukum Indonesia, (Bandung: Armico, 1985), h. 147 .

2 Berperan di sini memiliki arti masyarakat bertindak layaknya sebagai polisi, jaksa dan hakim. Sehingga berhak memutuskan dan mengeksekusi pelaku yang di duga melakukan kejahatan. 
penjambret hingga babak belur, membakar bus dan sopirnya karena di duga telah menabrak pengendara sepeda motor. Ini tentunya menjadi persoalan bagi kewibawaan penegak hukum itu sendiri. Tapi ini merupakan fenomena yang biasa dalam masyarakat kita.

Sebenarnya apa apakah dengan masyarakat kita yang kian mudah dirasuki amarah, dan mudah merusak serta membunuh secara missal. Agaknya kini telah menjadi hal yang biasa ketika kita mendengar pencopet dianiaya hingga tewas atau tawuran pelajar disana-sini yang menelan korban puluhan nyawa. Berbagai kerusuhan dan perang saudara disana-sini juga seakan tidak pernah usang dan sejarah. Bagaimana dengan supremasi hukum dan dinegeri tercinta ini, apakah menjadi sah sebuah kejahatan, seperti penganiayaan, perusakan dan pembunuhan bila dilakukan secara massal?

Terbukti kalau kita mengamati dengan maraknya pemberitaan di media massa, baik cetak maupun elektronik (BUSER, SERGAP, PATROLI), ${ }^{3}$ sering menyajikan peristiwa-peristiwa kekerasan yang dilakukan sekelompok masyarakat terhadap orang-orang yang diduga sebagai pelaku tindak kejahatan tertentu. Dari tayangan media-media tersebut atau yang kita saksikan di sekitar kita, tindakan kekerasan massa terhadap orangorang yang tertangkap tangan oleh masyarakat ketika sedang melakukan suatu tindak kejahatan itu, bisa dikatakan tidak sedikit. Peristiwa tersebut telah menimbulkan banyak korban nyawa dari orang-orang yang diduga sebagai pelaku tindak pidana kejahatan. Bahkan tidak jarang masyarakat melakukan hal-hal yang

3 Buser, Sergap, Patroli merupakan acara beberapa televisi di Indonesia yang menyajikan berita kriminal. Berbagai bentuk kejahatan yang terjadi di ungkap di dalamnya, salah satu yang sering yang juga kita jumpai dalam tayangan ini adalah kekerasan massa terhadap pelaku tindak kejahatan. 
sifatnya di luar batas kemanusiaan dalam memperlakukan pelaku kejahatan yang tertangkap tangan.

Seorang antropolog dari Cambridge University Inggris, Ray Abraham menyebut aksi sekelompok masyarakat yang secara langsung turun tangan menegakkan tertib hukum sebagai "vigilantisme citizen". Fenomena sosial ini menurut beliau, selalu berkaitan dengan persoalan hubungan antara masyarakat (society) dengan negara (state), dimana para pelaku menganggap negara terlalu lemah, kurang berminat, bahkan mungkin tidak mau melakukan pengendalian kejahatan (crime control). Oleh karena itu mereka (warga masyarakat) mengambil alih peran negara dalam menegakkan tertib hukum (law and order).

Misalnya tidak jarang kita saksikan bagaimana massa membakar orang karena mencuri seekor ayam, penjambret yang di keroyok puluhan massa penghakiman pencuri sepeda motor hingga tewas, atau menelanjangi dan mengarak sepasang pezina yang tertangkap basah. Dan sesudah itu tidak ada proses pengadilan. Sebenarnya ada apakah dengan masyarakat kita yang kian mudah di rasuki, dan mudah merusak serta membunuh secara massal?, bahkan sebagian masyarakat seringkali melakukan pembenaran bahwa tindakannya merupakan reaksi sosial informal terhadap adanya gangguan keseimbangan di dalam masyarakat.

Apa yang dilakukan oleh masyarakat dengan mengabaikan para penegak hukum tidak bisa ditolerir. Dengan mengatasnamakan massa, kerumunan tanpa ikatan, tidak lantas otomatis terbebas dari hukuman. Karena ini akan menciderai supremasi hukum itu sendiri.

Di sisi lain, dalam kitab-kitab fiqh terdapat bagian yang membahas tentang hukum pidana Islam, dengan judul jarimah. Di antara jarimah tersebut adalah membahas tentang tindak pidana terhadap nyawa, 
penganiayaan, dan luka-luka. ${ }^{4}$ Semua itu menggambarkan betapa luas dan dalamnya masalah hukum pidana Islam termasuk di dalamnya tentang tindak pidana terhadap nyawa, penganiayaan dan luka-luka.

Al-Mawardi menggunakan jarimah (jama'nya jaraim) untuk pengertian tindak pidana. Tindak pidana ialah semua larangan hukum syar'iyah yang di ancam Allah dengan hukuman had atau hukuman ta'zir.

Dalam tulisan ini akan dideskripsikan tentang tindak pidana penganiayaan, baik dalam kajian hukum pidana Islam maupun hukum pidana positif.

\section{B. Tindak Pidana Penganiayaan dalam Hukum Pidana Islam}

Menurut ahli fiqh, yang dimaksud pidana penganiayaan adalah menyakiti badan dan tidak sampai menghilangkan nyawa, baik itu menganiaya atau menyakiti, dan termasuk juga melukai, memukul, menarik, memeras, memotong rambut, dan mencabutnya, dan lain sebagainya. Para ahli hukum pidana Mesir menafsirkan bahwa yang dimaksud menganiaya adalah melukai dan memukul saja, pendapat ini menganggap bahwa melukai dan memukul termasuk hal yang menyakiti, tetapi para ahli hukum Mesir menganggap bahwa memukul dan melukai mencakup semua perbuatan yang ditimpakan pada badan yang berdampak pada jasmani dan rohani. Maka barang siapa mencekik seseorang dan menariknya, maka hal itu dianggap memukul dengan sengaja. Tindak pidana penganiayaan biasa di kenal dengan istilah $\mathrm{Al}$ Jinayat ala-Maa-Duni al-Nafs. Istilah ini sebagai imbangan dari tindak pidana terhadap nyawa (Al-Jinayat ala alNafs). Tindak pidana terhadap selain nyawa (penganiayaan) itu berupa semua rasa sakit yang menimpa pada badan manusia yang datang dari sesama

4 Sudjari Dahlan, "Sudut Pandang Terhadap Rancangan KUHP", dalam Makalah, Surabaya, 2001, h. 2 . 
manusia yang lain. ${ }^{5}$ Tetapi tidak sampai menghilangkan keselamatan hidupnya. Dengan perkataan lain tindak pidana penganiayaan adalah semua tindakan melawan hukum dan tindakan seseorang kepada orang yang membahayakan atau mendatangkan rasa sakit pada badan dan atau anggota badan manusia. ${ }^{6}$

Tindak pidana penganiayaan ini adakalanya disengaja dan terkadang karena kesalahan. Tindak pidana penganiayaan sengaja yaitu perbuatan yang disengaja oleh pelakunya dengan sikap permusuhan. Adapun penganiayaan tidak sengaja seperti orang melempar batu dengan sengaja tetapi tidak bermaksud melempar orang dengan sikap permusuhan seperti membuang batu lewat jendela ketika membersihkan rumah, tiba-tiba mengenai orang lewat. ${ }^{7}$

\section{Jenis-jenis Tindak Pidana Penganiayaan} yaitu:

Tindak pidana penganiayaan dibagi menjadi dua,

a. Tindak Pidana Penganiayaan Dengan Sengaja

Penganiayaan sengaja ialah seseorang yang sengaja melakukan perbuatan pidana dan mengenai tubuh korban yang mengancam keselamatannya. Tindak pidana dikatakan sengaja, bila memenuhi dua syarat :

1) Perbuatan tersebut mengenai tubuh korban dan mengancam keselamatannya.

2) Perbuatan tersebut dilakukan dengan sengaja.

Dalam pidana penganiayaan sengaja, alat yang dipakai oleh pelaku tidak penting, entah dia memakai tangan, kaki, gigi, atau mungkin memakai tongkat, pisau, pedang, tombak, atau alat-alat yang berbahaya lainnya.

${ }^{5}$ Abd al-Qādir al-Audah, al-Tashrī al-Jina’iy al-Islāmy Muqāran b alQānun al-Wad'iy, (Ttp.: Maktabah Dār al-Urubah, tt.), h. 204.

${ }^{6}$ Sudjari Dahlan, Sudut Pandang Terhadap Rancangan KUHP, h. 9.

7 Ibid., h. 9. 
Menurut Imam Ahmad, bahwa penganiayaan dibagi menjadi dua, yaitu : sengaja dan tidak disengaja. Perbedaannya terletak pada hukumannya, yang pertama diqisas dan kedua diyat. ${ }^{8}$

Abu Hanifah tidak membeda-bedakan antara penganiayaan yang sengaja dan tidak disengaja, kecuali terhadap jiwa, jadi cukup dilihat dari kesengajaannya dalm perbuatannya. Menurut Imam Malik dan Syafi'i bahwa seorang pelaku pidana bertanggungjawab terhadap perbuatannya walaupun pidana tidak langsung ditimbulkan oleh perbuatannya seperti seseorang yang minta pedang pada orang lain dan dibawa lari kemudian merobohkan atap dan mengenai orang sehingga terluka, karena sesungguhnya dialah yang melindungi korban dari robohnya atap tersebut.

Imam Syafi'i berpendapat bahwa penganiayaan ada dua, yaitu kesengajaan murni dan semi sengaja. Kesengajaan adalah adanya niat untuk berbuat sedangkan semi sengaja tidak ada maksud untuk menimbulkan sesuatu.

b. Tindak pidana penganiayaan tidak sengaja

Tindak pidana penganiayaan tidak sengaja adalah suatu perbuatan yang dianggap Jarimah, tapi apabila pelaku bermaksud melakukan perbuatan dan tidak berniat membunuhnya maka perbuatan tersebut dianggap tidak sengaja. Seorang pelaku pidana akan ditanyakan akibat yang ditimbulkan dari perbuatannya, bukan dari niat atau maksud ketika terjadinya suatu perbuatan. Jadi ketika dia menghilangkan salah satu anggota tubuh korban, menghilangkan manfaatnya, maka dia akan ditanya dan dimintai pertanggungjawaban sebesar nilai yang ditimbulkan dari perbuatan tersebut bukan seberapa besar niat yang ada dalam dirinya ketika mengerjakan

${ }^{8}$ Abd al-Qādir al-Audah, al-Tashrī al-Jina’’iy, h. 205. 
perbuatan tersebut. Seorang pelaku pidana juga ditanya tentang maksud melakukan perbuatan, maka barang siapa yang melemparkan batu pada sekelompok orang dengan maksud biar mengenai salah seorang dari mereka maka dia akan ditanya tentang akibat dari perbuatannya, baik dia mengetahui mereka atau tidak.

Perbuatan tersebut dianggap tindak pidana penganiayaan, apabila seorang pelaku pidana sengaja berbuat tapi tidak bermaksud untuk membunuh, atau sengaja berbuat untuk tidak menimbulkan kematian. Baik melukai atau merusak sebagian anggota tubuh.

\section{Macam-Macam Tindak Pidana Penganiayaan}

Fuqaha' membagi tindak pidana penganiayaan ini, baik yang disengaja maupun yang tidak disengaja menjadi lima bagian: ${ }^{9}$

a. Bagian yang menerangkan anggota-anggota tubuh manusia dan apa yang berlaku sebagai anggota tubuh. Maksudnya: memisahkan anggota tubuh, memotongnya, dan memutuskan sesuatu yang mangalir darinya, seperti memotong tangan, kaki, jarijari, hidung, kemaluan, telinga, dan lain sebaginya.

b. Menghilangkan makna/substansi anggota tubuh tetapi secara formal anggota tubuh tetap ada. Maksudnya: perbuatan ini hanya menghilangkan manfaat dan fungsi dari anggota tubuh tanpa menghilangkannya, seperti menghilangkan fungsi pendengaran, penglihatan, penciuman, rasa, bicara, jima', dan lain sebagainya termasuk juga menghilangkan akal.

c. Luka-luka pada kepala. Maksudnya: luka di kepala dan wajah, adapun luka pada anggota tubuh yang lain selain kepala dan wajah disebut jarah, dan orang membedakan antara luka di kepala dan luka di lain

${ }^{9}$ Ibid., h. 9.

Al-Qānūn, Vol. 20, No. 1, Juni 2017 
kepala. Luka-luka pada kepala menurut Abu Hanifah dibagi menjadi sebelas bagian:

1) Al-Kharishah, yaitu luka di kulit kepala dan tidak mengeluarkan darah.

2) Ad-Dami'ah, yaitu luka di kulit kepala sehingga mengeluarkan darah, seperti air mata mengalir dari mata.

3) Ad-Damiyah, yaitu luka di kulit sampai darahnya mengalir.

4) Al-Badzi'ah, yaitu luka di daging setelah kulit.

5) Al-Muthalimah, yaitu apabila luka yang di daging itu lebih besar dari al-badzi'ah.

6) Al-Syimhaq, yaitu luka yang menghabiskan semua daging di bawah kulit hingga tidak tersisa di kulit kepala kecuali lapisan tipis.

7) Al-Muwadzdzihah, yaitu luka di kulit, daging dan lapisan di tengkorak kepala, hingga tengkorak kepala kelihatan.

8) Al-Hasyimah, yaitu luka hingga tengkorak kelihatan dan memecahkannya.

9) Al-Muhaqqilah, yaitu luka parah higga tengkorak kepala kelihatan pecah dan terkeping-keping serta terpisah dari tempat semula dan perlu dikembalikan lagi.

10) Al-Amatu, yaitu luka dikepala sampai ke tulang tengkorak dan sebelum otak.

11) Al-Damighah, yaitu luka yang menembus selaput otak.

c. Luka-luka pada anggota badan yang lain (al-Jarah). Maksudnya: yaitu luka di sekujur tubuh selain kepala dan wajah.

d. Semua yang tidak termasuk pada empat macam di atas. Maksudnya: adalah menyakiti atau menganiaya tetapi tidak sampai menghilangkan anggota tubuh dan fungsinya. ${ }^{10}$

10Abd al-Qādir al-Audah, al-Tashrīal-Jinåìy, h. 208. 
Suatu kejahatan kadang-kadang dilakukan oleh satu orang dan ada kalanya dilakukan oleh beberapa orang. Oleh karena itu, bahasan terpenting tentang perbuatan Jarimah yang dilakukan oleh beberapa orang diantaranya: turut berbuat Jarimah langsung dan tidak langsung, hubungan antara turut berbuat Jarimah langsung dengan berbuat Jarimah tidak langsung, turut berbuat Jarimah tidak langsung dengan cara tidak melakukan sesuatu, dan tanggung jawab pidana terhadap kemungkinan terjadinya kejahatan diluar kesepakatan semula.

Para fuqaha' hanya membicakan hukum "turut berbuat langsung" (isytirak mubasyir), sedang hukum "turut berbuat tidak langsung" (isytirak ghoiru mubasyir) boleh dikata tidak disinggung-singgung. Boleh jadi hal ini disebabkan karena menurut syari'at Islam, hukuman yang telah ditentukan hanya dijatuhkan atas orang yang turut berbuat dengan langsung, bukan atas orang yang turut berbuat tidak langsung.

Akan tetapi fuqaha' mengecualikan pidana pembunuhan dan penganiayaan serta ketentuan aturan umum tersebut yakni untuk kedua macam pidana ini, baik perbuatan langsung ataupun tidak langsung dijatuhi hukuman. Alasannya ialah karena kedua pidana tersebut bisa dikerjakan dengan langsung dan tidak langsung, sesuai dengan sifat-sifat pidana tersebut. Kalau kita berpegangan keseluruhnya dengan aturan tersebut maka akibatnya banyak perbuatan tidak langsung yang terhindar dari hukuman, sedang ia sebenarnya turut serta melaksanakan pidana tersebut.

Jadi, berdasarkan aturan tersebut perbuatan pidana tidak langsung (meminjam tangan atau orang yang menghasud) apabila turut melakukan pidana yang diancam hukuman tertentu, maka tidak dikenakan dengan hukuman itu sendiri, sebab hukuan tersebut hanya diancamkan pada pembuat pidana langsung. Dengan perkataan lain perbuatan pidana tidak langsung termasuk 
Jarimah ta'zir, baik perbuatan yang dikerjakan itu termasuk Jarimah hudud atau qisas atau diyat.

Dari sini kita dapat memahami mengapa para fuqaha' tidak membicarakan secara khusus terhadap soal turut berbuat tidak langsung, sebab perbuatan tersebut Jarimah hudud dan qisas, yaitu Jarimah yang mendapat perhatian utama dari mereka.

Meskipun demikian perbuatan tersebut disinggungsinggung juga oleh mereka ketika membicarakan Jarimah pembunuhan dan penganiayaan.

\section{a. Turut Berbuat Langsung}

Pada dasarnya turut berbuat langsung baru terdapat apabila orang-orangorang yang berbuat Jarimah denngan nyata lebih dari seorang atau yang biasa disebut dikalangan sarjana-sarjana hukum positif dengan nama "berbilangnya pembuat asli" (mede daders). ${ }^{11}$

Turut berbuat langsung dapat terjadi, manakala seorang melakukan suatu perbuatan yang dipandang sebagai permulaan Jarimah yang sudah cukup disifati dengan maksiat, yang dimaksudkan untuk melaksanakan Jarimah itu. Dengan istilah sekarang ialah apabila ia telah melakukan percobaan, baik Jarimah yang diperbuatnya itu selesai atau tidak, karena selesai atau tidaknya sesuatu Jarimah tidak mempengaruhi kedudukannya sebagai orang yang turut berbuat langsung. Pengaruhnya hanya terbatas pada besarnya hukuman, yaitu apabila Jarimah yang diperbuatnya itu selesai, sedang Jarimah itu berupa Jarimah had, maka yang berbuat dijatuhi hukuman had, dan kalau tidak selesai maka hanya dijatuhi hukuman ta'zir.

Akan tetapi para fuqaha' menyamakan hukuman beberapa bentuk turut berbuat tidak langsung dengan turut berbuat langsung, meskipun pada bentuk pertama

11 Ahmad Hanafi, Asas-asas Hukum Pidana Islam, (Jakarta: Bulan Bintang, 2005), h. 138 
tersebut tidak langsung. Pelaku pidana tidak turut melakukan sendiri unsur materi Jarimah. Berdasarkan kedua contoh tersebut palaku tindak pidana dijatuhi hukuman sebagai orang yang turut berbuat langsung.

Orang yang berbuat Jarimah sendirian atau bersama-sama orang lain. Jika masing-masing dari tiga orang megarahkan tembakan pada korban dan mati karena tembakan itu maka ketiga orang tersebut dianggap melakukan pembunuhan. Demikian pula apabila mereka bersama-sama mengambil barang orang lain, masingmasing dianggap sebagai pencuri. Dalam hal ini, fuqaha' mengadakan pemisahan apakah kerja sama dalam mewujudkan Jarimah secara kebetulan, atau memang sudah direncanakan secara bersama-sama sebelumnya. Hal yang pertama disebut "tawafuq" dan hal kedua disebut "tamalu"'.12

Pada "tawafuq" niat peserta dalam berbuat Jarimah, tanpa ada kesepakatan sebelumnya melainkan masingmasing peserta berbuat karena dorongan pribadi dan pikirannya yang timbul seketika itu, seperti yang sering terjadi pada kerusuhan-kerusuhan dalam demonstrasi atau perkelahian secara pengeroyokan.

Pada "tamalu"' para pesrta telah bersepakat untuk berbuat Jarimah dan menginginkan bersama terwujudkan hasil Jarimah itu, serta saling membantu dalam melaksanakannya. Apabila ada dua orang bersepakat untuk membunuh orang ketiga, kemudian kedua-duanya pergi, lantas yang satu mengikat korban dan yang lain memukul kepalanya sehingga mati, maka kedua-duanya bertanggung jawab atas kematiannya tersebut.

Menurut kebanyakan fuqaha' ada perbedaan pertanggungjawaban antara "tawafuq" dengan "tamalu". Pada "tawafuq" masing-masing peserta hanya bertanggung jawab atas akibat perbuatannya saja, dan tidak bertanggung jawab atas perbuatan yang lain. Akan

12 Ibid., h. 142.

Al-Qānūn, Vol. 20, No. 1, Juni 2017 
tetapi pada "tamalu", para peserta harus mempertanggungjawabkan perbuatannya secara keseluruhan. Jika korban mati, maka masing-masing peserta dianggap sebagai pembunuh.

Menurut syariat Islam dalam persoalan turut berbuat langsung sama dengan Jarimah percobaan yakni menghukum berdasarkan niatan pelaku.

\section{b. Turut Berbuat Tidak Langsung}

Yang dianggap turut berbuat tidak langsung adalah setiap orang yang mengadakan perjanjian dengan orang lain untuk melakukan sesuatu perbuatan yang dapat dihukum, atau menyuruh orang lain atau memberikan bantuan dalam perbuatan tersebut yang disertai kesengajaan dalam kesepakatan dan menyuruh serta memberi bantuan. ${ }^{13}$

Dari keterangan tersebut kita mengetahui unsurunsur turut berbuat tidak langsung, yaitu:

1) Perbuatan yang dapat dihukum.

Yang dimaksud dengan perbuatan yang dapat dihukum adalah perbuatan yang dikerjakan secara tidak langsung dan memberi bagian dalam pelaksanaannya, tidak diperlukan harus selesai dan juga tidak diperlukan bahwa pelaku langsung harus dihukum pula. Jadi pada Jarimah percobaan kawan berbuat tidak langsung dapat pula dihukum.

2) Niatan dari orang yang turut berbuat, agar niat perbuatan yang dimaksudkan dapat terjadi.

Yang dimaksud dengan kesepakatan atau hasutan dan bantuan disebutkan oleh kawan berbuat tidak langsung untuk terjadinya sesuatu pidana tertentu. Kalau tidak ada pidana tertentu yang maksudkan, maka ia dianggap turut berbuat pada setiap Jarimah yang terjadi, apabila dimungkinkan oleh niatnya. Kalau pidana yang terjadi bukan yang

13 Ibid., h. 144.

Al-Qānūn, Vol. 20, No. 1, Juni 2017 
dimaksudkannya maka tidak ada turut berbuat, meskipun karena kesepakatan dan bisa dijatuhi hukuman.

3) Cara mewujudkan perbuatan tersebut yaitu mengadakan kesepakatan, menyuruh, dan membantu.

Kesepakatan bisa terjadi karena adanya saling memahami dan karena kesaman kehendak untuk melakukan pidana. Kalau tidak ada kesepakatan sebelumnya, maka tidak ada turut berbuat. Untuk terjadinya sesuatu Jarimah harus merupakan akibat kesepakatan. Jika seseorang bersepakat dengan orang kedua untuk membunuh orang ketiga, kemudian orang ketiga tersebut telah mengetahui apa yang akan diperbuat terhadap dirinya dan oleh karena itu ia pergi ke tempat orang kedua tersebut. Dan ia (orang ketiga) itu hendak membunuhnya terlebih dahulu, akan tetapi orang kedua itu dapat membunuh orang ketiga terlebih dahulu karena untuk membela diri, maka kematian orang ketiga tersebut tidak dianggap sebagai akibat kesepakatan, melainkan karena akibat pembelaan diri dari orang kedua. ${ }^{14}$

\section{c. Pertalian Antara Turut Berbuat Jarimah Langsung dan Berbuat Jarimah Tidak Langsung}

Para Ulama' sepakat bahwa pelaku langsung itu harus dikenai hukuman meskipun ia melaksanakan perbuatan itu bersama orang lain, hanya saja hukuman yang dikenakan kepada setiap pelaku itu sangat tergantung pada sifat perbuatannya, sifat pelakunya dan niat si pelaku. ${ }^{15}$

Bentuk lain dari turut berbuat Jarimah langsung adalah menghasut orang lain untuk berbuat kejahatan sehubungan dengan ini ada tiga syarat bagi terjadinya turut berbuat Jarimah, yaitu:

14 Ibid., h. 144-145.

15 A. Djazuli, Fiqh Jinayah: Upaya Menanggulangi Kejahatan dalam Islam, (Jakarta: Raja Grafindo. 1997), h. 18. 
1) Adanya perbuatan yang diancam dengan hukuman (Jarimah)

2) Adanya cara yang menuju kepada perbuatan tadi, seperti adanya kesepakatan untuk berbuat suatu Jarimah, atau membantu melakukan suatu kejahatan.

3) Adanya tujuan dari setiap pelaku demi terjadinya suatu perbuatan yang diancam hukuman. ${ }^{16}$

\section{d. Tanggung jawab pidana terhadap kemungkinan terjadinya kejahatan di luar kesepakatan yang semula}

Menurut Imam Hanafi, Imam Syafi'i, dan Imam Hambali si penyuruh terhadap tindak pidana itu bertanggungjawab terhadap terjadinya Jarimah tersebut. Ini berbeda dengan Imam Maliki, menurut Imam Maliki si penyuruh bertanggung jawab atas Jarimah kesalahan. Dia beralasan karena perintahnya itu memungkinkan terjadinya Jarimah.

\section{Hukuman Tindak Pidana Penganiayaan}

Pidana tindak pidana penganiayaan pada dasarnya (hukuman pokoknya) adalah Qisas, jika tidak mungkin untuk dilaksanankan ${ }^{17}$ atau di maafkan oleh keluarga korban, maka hukuman penggantinya adalah diyat. Jika sanksi qisos atau diyat di maafkan, maka hukuman penggantinya adalah ta'zir. ${ }^{18}$

16 Ibid., h. 19 .

17 Untuk hukuman penganiayaan adalah qisas, hal ini diqiyaskan dengan hukuman pembunuhan., hal ini penulis dasarkan pendapat Imam Asy-Safi'I dalam kitab Al-Umm. Lihat: al-Shāfi'iy, al-Umm, Jilid III (Beirut: Dār al-Fikr, tt.), h. 182-188.

18 Tidak semua penganiayaan dapat di hukum dengan qisas adapun yang tidak bisa di hukum dengan qisas adalah luka dikepala dan di wajah. Untuk penganiayaan yang terdapat luka di kepala wajah dan kepala adalah diyat. Lihat: al-Mawardi, Prinsip-prinsip Penyelenggaraan Negara Islam, Terj. Fadhli Bahri (Jakarta: Darul Falah, 2000), h. 388. 


\section{a. Sanksi tindak pidana penganiayaan yang dilakukan secara berserikat}

Penganiayaan yang dilakukan oleh sekelompok orang terhadap satu orang maka mereka semuanya terkena hukumam Qisas Baik jumlah mereka banyak ataupun sedikit, meskipun di antara mereka tidak melakukan penganiayaan secara langsung. ${ }^{19}$

Selanjutnya menurut Imam Syafi'i dalam kitabnya Al-Umm, beliau mengatakan : .............Bagi para wali (orang-orang yang melakukan penganiayaan) darah kalau mereka menginginkan mereka secara bersamaan, maka dia boleh mengqisos mereka dan jika mereka menginginkan boleh mengambil dari mereka itu diyat. ${ }^{20}$

Mereka wajib membayar satu diyat (ganti rugi), kendati jumlah mereka banyak. Keluarga korban berhak memaafkan salah seorang dari para penganiaya dan menqisas sisanya. Jika keluarga korban memaafkan semua penganiaya, mereka harus membayar satu diyat (ganti rugi) tanpa menghitung jumlah mereka..

Bagi sekelompok orang yang melakukan penganiayaan terhadap seseorang dengan memakai senjata alat yang umumnya dan secara tabiatnya dapat digunakan untuk membunuh seperti besi, pedang, tombak, dll hingga seseorang tersebut meninggal maka semua orang yang memukul dihukum sebagai penganiaya, dan setiap mereka dihukum qishsah. ${ }^{21}$

\section{b. Sanksi tindak pidana bagi pelaku utama}

Bagi pelaku utama dalam penganiayaan sekelompok orang/berserikat menurut empat madzab di ancam dengan hukuman qisos. ${ }^{22}$ Akan tetapi mereka berbeda pendapat jika anggota kelompok tersebut

19 Ibid., h. 139.

${ }^{20}$ Al-Shāfi'iy, al-Umm, Jilid III, h. 183.

21 Ibid., h. 199.

${ }^{22}$ A. Djazuli, Fiqh Jinayah, h. 138. 
membantu, memegang, memerintah dan dipaksa untuk menganiaya.

Pelaku utama dapat diartikan, manakala seorang melakukan sesuatu perbuatan yang dipandang sebagai permulaan pelaksanaan Jarimah yang sudah cukup disifati sebagai ma'siat, yang dimaksud untuk melaksanakan Jarimah itu. Dengan istilah sekarang ialah apabila ia telah melakukan percobaan, baik Jarimah yang diperbuatnya itu sesuai atau tidak, karena selesai atau tidaknya sesuatu Jarimah tidak mempengaruhi kedudukannya sebagai orang yang turut berbuat langsung. Pengaruhnya hanya terbatas pada besarnya hukuman, yaitu apabila Jarimah yag diperbuatnya itu selesai, sedang Jarimah itu berubah Jarimah had, maka pembuat dijatuhi hukuman had, dan kalau tidak selesai maka hanya dijatuhi hukuman $t a^{\prime} z i r .{ }^{23}$

\section{c. Sanksi tindak pidana bagi selain pelaku utama}

Yang dimaksud dengan tindak pidana selain pelaku utama adalah setiap orang yang mengadakan perjanjian dengan orang lain utnuk melakukan sesuatu perbuatan yang dapat dihukum, atau menyuruh orang lain memberikan bantuan dalam perbuatan tersebut dengan disertai kesengajaan dalam kesepakatan dan menyuruh serta memberi bantuan. ${ }^{24}$

Untuk tindak pidana bagi selain pelaku di bagi empat macam, yaitu: ${ }^{25}$

\section{1) Membantu penganiayaan}

Orang yang memberi bantuan kepada orang lain dalam memperbuat tindak pidana kejahatan dianggap sebagai kawan-berbuat tidak-langsung, meskipun tidak ada kesepakatan untuk itu sebelumnya. ${ }^{26}$

23 Ahmad Hanafi, Asas-asas Hukum Pidana Islam, h. 139.

24 Ibid., h. 144.

${ }^{25}$ A. Djazuli, Fiqh Jinayah, h. 139-143.

${ }^{26}$ Ahmad Hanafi, Asas-asas Hukum Pidana Islam, h. 147. 
Dalam hal penganiayaan Imam Safi'i dan ImamImam yang lain orang yang membantu dianggap penganiya hal ini terjadi karena tamalu' (ada kesepakatan untuk menganiaya. Meskipun pebuatan pembantu bukan menganiya, namun perbuatannnya bersama dengan anggota kelompok lainnya menyebabkan luka-luka pada korban dan luka-luka tersebut akibat dari perbuatan kelompok. Namun AsSafi'i berpendapat bahwa yang dikenai qisos hanyalah orang yang menganiaya langsung. ${ }^{27}$

\section{2) Memegang orang yang akan dianiaya}

Dan bagi yang memegang orang yang akan dianiaya, dan ia memegang bukan untuk menganiaya tidak dapat di qisos. Menurut Imam Syafi'i orang tersebut di ancam dengan hukuman ta'zir.

\section{3) Memerintah/diperintah menganiaya}

Sementara dalam kasus memerintah orang lain untuk membunuh para ulama berbeda pendapat. Menurut Imam Malik, Imam Ahmad dan Syafi'i, hukuman qisos dikenakan kepada orang yang memerintah, karena yang diperintah itu hanya sebagai alat yang digerakkan oleh orang yang memerintahkannya. Dan untuk yang diperintah diancam dengan hukuman ta'zir.

Tetapi jika yang disuruh orang dewasa, berakal sehat, dan yang menyuruh tidak memiliki kekuasaan atas yang disuruh, maka yang di qisos adalah pelaku yang langsung. Sedang yang menyuruh di kenakan ta/zir

\section{4) Di paksa untuk menganiaya}

Sedangkan untuk kasus pemaksaan untuk penganiayaan Madzab Syafi'i maupun Madzhab Malik, Ahmad berpendapat bahwa baik orang yang memaksa maupun yang dipaksa di ancam hukuman qisos. Hal ini didasarkan karena orang yang memaksa itu penyebab

${ }^{27}$ A. Djazuli, Fiqh Jinayah, h. 138. 
luka-luka. Sedangkan orang yang dipaksa melakukan penganiayaan demi menyelamatkan diri sendiri. Dalam hal perbuatan sebab dan langsung itu seimbang.

\section{Tindak Pidana Penganiayaan dalam Hukum Pidana Indonesia}

1. Kemampuan bertanggung jawab dalam tindak pidana penganiayaan

Kemampuan bertanggung jawab ini tercantum dalam Kitab Udang-Undang Hukum Pidana pasal 44, yaitu : "Apabila yang melaukan perbuatan pidana itu tidak dapat mempertanggungjawabkan disebabkan karena pertumbuhan yang cacad atau adanya gangguna karena penyakit dari pada jiwanya maka orang itu tidak dipidana".28

Sedangkan orang yang mampu bertanggung jawab itu harus memenuhi tiga syarat $:^{29}$

a. Dapat menginsyafi makna yang senjatanya dari pada perbuatanya.

b. Dapat menginsyafi bahwa perbuatannya itu tidak dapat dipandang patut dalam pergaualan masyarakat.

c. Mampu untuk menentukan niat atau kehendaknya dalam melakukan perbuatan.

Mampu bertanggung jawab disini berarti mampu untuk menginsyafi sifat melawan hukumnya perbuatan dan sesuai dengan keinsyafan itu mampu untuk menentukan kehendaknya.

Untuk menentukan adanya kemampuan bertanggung jawab ini ada dua faktor yaitu :

a. Faktor akal

Yaitu dapat membeda-bedakan antara perbuatan yang diperbolehkan dan yang tidak diperbolehkan.

28 Moeljatno, KUHP (Kitab Undang-Undang Hukum Pidana), (Jakarta: Bumi Aksara. 2007), h. 21.

29 Roeslan Saleh Perbuatan Pidana dan Pertanggungjawab Pidana, (Jakarta: Aksara Baru, 1983), h. 85. 
b. Faktor kehendak

Yaitu dapat menyesuaikan tingkah lakunya dengan keinsyafan atas nama diperbolehkan dan mana yang tidak.

\section{Kesengajaan dan kealpaan dalam tindak pidana penganiayaan}

Baik kesengajaan dan kealpaan ini kedua-duanya merupakan bentuk kesalahan. Tidak ada salah satu diantara keduanya ini berarti tidak ada kesalahan. Tanpa adanya kesalahan, maka tidak dipidana.

Untuk membuktikan tentang kesengajaan kita dapat menempuh dua jalan :

a. Membuktikan adanya hubungan kausal dalam bathin terdakwa antara motif dan tujuanya atau,

b. Membuktikan adanya penginsyafan atau pengertian terhadap apa yang dilakukannya beserta akibat-akibat dan keadaan-keadaan yang menyertainya.

Sedang mengenai kealpaan tidak ada keterangan yang jelasa dalam KUHP. Hal ini diserahkan pada praktek pengadilan.

\section{Perbuatan yang dapat dihukum dalam tindak pidana penganiayaan}

Perbuatan yang dapat dihukum dapat disebut dengan beberapa istilah lain, yaitu :

a. Tindak pidana,

b. Peristiwa pidana,

c. Delict

"Delict" ialah suatu perbuatan atau rangkaian perbuatan manusia, yang bertentangan dengan undangundang atau peraturan hukum lainnya, yang dilakukan dengan sengaja oleh orang yang dapat dipertanggungjawabkan.

Menurut definisi tersebut ada beberapa anasir yang perlu diperhatikan yaitu :

a. Perbuatan manusia 
b. Perbuatan itu harus sesuai dengan apa yang dilukiskan di dalam ketentuan hukum.

c. Harus terbukti adanya "dosa" (salah) pada orang yang berbuat, yaitu orang yang dapat dipertanggungjawabkan

d. Perbuatan itu harus berlawanan dengan hukum.

e. Terhadap perbuatan itu harus bersedia ancaman hukumannya didalam undang-undang.

4. Hal-hal yang meringankan atau membebaskan hukuman

Di dalam hukum pidana kita mengenal perbuatanperbuatan yang merupakan kejahatan yang tidak dapat dihukum. ${ }^{30}$

Tentang tidak dapat dihukumnya ini disebabkan karena beberapa hal :

a. Karena sebab yang ada pada diri orang sendiri,

Karena sebab yang ada pada diri orang itu sendiri tercantum dalam pasal 44 ayat (1) KUHP: "Barangsiapa mengerjakan sesuatu perbuatan, yang tidak dapat dipertanggungjawabkan kepadanya karena kurang sempurna akalnya atau karena sakit berubah aka, tidak boleh dihukum". ${ }^{31}$

b. Karena sebab dari luar keadaan si pembuat.

Yang termasuk disini adalah :

1) Dalam keadaan berat lawan

2) Dalam keadaan darurat

3) Karena membela diri

4) Karena melaksanakan peraturan undang-undang

5) Karena melaksanakan perintah yang diberikan kepada pegawai negeri dengan sah.

\section{Turut Serta Melakukan Tindak Pidana}

Adapun ketentuan mengenai tindak kekerasan massa yang dalam KUHP tercantum dalam bab V Buku

30 Samidjo, Pengantar Hukum Indonesia, h. 154.

31 Moeljatno, KUHP, h. 21-22 . 
Kesatu yaitu tentang penyertaan dalam melakukan perbuatan pidana terdiri atas 7 pasal, yaitu pasal 55,56 , dan 57.

Aturan tersebut berlaku umum, artinya melihat pada akibat dari perbuatan tindak pidana. Kalau kekerasan massa mengakibatkan mati maka mengenai aturan masing-masing orang yang turut serta melakukan tindak pidana tersebut mengacu pada pasal diatas. Begitu juga umpamanya tindak pidana kekerasan massa yang mengakibatkan luka-luka (penganiayaan) maka untuk aturan masing-masing yang terlibat dalam penganiayaan tersebut juga mengacu pada pasal diatas (pasal tentang penyertaan).

Pengertian "turut serta" (turut campur; ikut serta; bersama-sama) melakukan peristiwa pidana dapat dilakukan oleh beberapa orang bersama. Turut campur dari beberapa orang di dalaam peristiwa pidana dapat merupakan kerja-sama, yang masing-masing dapat berbeda-beda sifat dan bentuknya. ${ }^{32}$

Tentang istilah "turut serta" ini adalah buah pikiran Von Feurbach, sarjana hukum bangsa Jerman, yang membagi dua jenis perserta, yaitu:

a. Mereka yang langsung berusaha terjadinya delik.

b. Mereka yang hanya membantu usaha yang dilakukan oleh mereka (1). (jadi pada B) adalah mereka yang tidak langsung berusaha. ${ }^{33}$

Pembagian dalam dua golongan inilah yang juga diterima dalam KUH Pidana, yaitu dalam:

a. Pasal 55, bahwa yang dianggap sebagai pelaku itu ialah: ${ }^{34}$

1) Orang yang melakukan

Orang ini ialah seorang yang sendirian telah berbuat mewujudkan segala anasir delik.

32Samidjo, Pengantar Hukum Indonesia, h. 162.

33 Ibid., h. 162.

${ }^{34}$ Moeljatno, KUHP, h. 25 . 
2) Orang yang menyuruh melakukan

Di sini sedikitnya ada dua orang yang menyuruh dan yang disuruh.

3) Orang yang turut melakukan

"Turut melakukan" dalam arti kata "bersama-sama melakukan". Sedikitnya harus ada dua orang ialah orang yang melakukan dan orang yang turut melakukan peristiwa pidana itu.

4) Orang yang membujuk melakukan

Orang yang dengan pemberian; salah memakai kekuasaan; memakai kekerasan dan sebagainya dengan sengaja membujuk melakukan suatu tindak pidana. ${ }^{35}$

b. Pasal 56, KHUP, disebut mereka yang "membantu" yang melakukan delik:

1) Ayat (1). Mereka yang sengaja memberi bantuan pada waktu kejahatan dilakukan.

Bunyi ayat tersebut bermakna bahwa segala bantuan pada waktu/saat dilakukan kejahatan, jadi merupakan suatu campur tangan yang dilakukan waktu/saat yang berbarengan.

2) Ayat (2). Mereka yang sengaja memberi kesempatan, sarana atau keterangan untuk melakukan kejahatan.

Sedang untuk ayat 2 bermakna, barangsiapa dengan sengaja memberi kesempatan, daya upaya atau keterangan untuk melakukan kejahatan itu. Disini bantuan dilakukan sebelum kejahatan dilakukan.

3) Adapun untuk pasal 57 memuat keterangan/rincian tentang "membantu" melakukan delik. Dengan bunyi sebagai berikut:

a) Dalam hal pembantuan, maksimum pidana pokok terhadap kejahatan, dikurangi sepertiga.

35Samidjo, Pengantar Hukum Indonesia, h. 163. 
b) Jika kejahatan diancam dengan pidana mati atau pidana penjara seumur hidup, dijatuhkan pidana penjara paling lama lima belas tahun.

c) Pidana tambahan bagi pembantuan adalah sama dengan kejahatannya sendiri.

d) Dalam menentukan pidana bagi pembantu, yang diperhitungkan hanya perbuatan yang sengaja dipermudah atau diperlancar olehnya, beserta akibat-akibatnya. ${ }^{36}$

\section{Sanksi Tindak Pidana Penganiayaan Dalam KUHP \\ a. Sanksi Penganiayaan}

Dalam Undang-Undang tidak memberikan perumusan apa yang dinamakan "penganiayaan". Namun menurut jurisprudensi pengadilan maka yang dinamakan "penganiayaan" adalah : ${ }^{37}$

1) Sengaja menyebabkan perasaan tidak enak (penderitaan).

2) Menyebabkan rasa sakit.

3) Menyebabkan luka.

Menurut Undang-Undang, penganiayaan itu dibedakan atas lima macam, yaitu: ${ }^{38}$

1) Penganiayaan biasa (pasal 351 KUHP)

Di ancam pidana penjara dua tahun delapan bulan atau denda paling banyak tiga ratus rupiah., Jika perbuatan luka-luka berat dikenakan penjara paling lama lima tahun. Sedang perbuatan mengkibatkan mati dikenakan penjara paling lama tujuh tahun. ${ }^{39}$

2) Penganiayaan ringan (pasal 352 KUHP)

Penganiyaan ringan ini diancam pidana penjara paling lama tiga bulan atau denda paling banyak tiga ratus rupiah.dan pidana dapat ditambah sepertiga

36Moeljatno, KUHP, h. 26.

37 Ibid., h. 144.

38 Ibid., h. 144.

${ }^{39}$ Moeljatno, KUHP, h. 123. 
bagi orang yang melakukan kejahatan itu terhadap orang yang bekerja padanya, atau menjadi bawahannya. ${ }^{40}$

3) Penganiayaan biasa yang direncanakan lebih dahulu (pasal 353 KUHP).

Penganiayaan dengan renacana di ancam dengan pidana penjara paling lama empat tahun, kalau mengakibatkan luka-luka berat diancam pidana penjara paling lama tujuh tahun. dan jika perbuatan mengakibatkan mati dikenakan pidana penjara paling lama sembilan tahun. ${ }^{41}$

4) Penganiayaan berat (pasal 354 KUHP) dan

Di ancam dengan hukuman pidana penjara paling lama delapan tahun jika sengaja melukai orang lain dengan pelukaan berat. Dan jika perbuatan mengakibatkan mati diancam pidana penjara paling lama seputuh tahun. ${ }^{42}$

5) Penganiayaan berat dengan direncanakan lebih dahulu (pasal 355 KUHP)

Penganiayaan berat direncanakan lebih dahulu diancam denga pidana penjara paling lama dua belas tahun. Dan jika mengakibatkan mati dikenakan pidana penjara paling lama lima belas tahun. ${ }^{43}$

\section{Penutup}

Dari berbagai pemaparan di atas, maka dapat disimpulkan:

1. Dalam fiqh jinayah, penganiayaan merupakan menyakiti badan dan tidak sampai menghilangkan nyawa, baik itu menganiaya atau menyakiti, dan termasuk juga melukai, memukul, menarik, memeras, memotong rambut, dan mencabutnya, dan lain

40 Ibid., h. 125.

41 Ibid., h. 125.

${ }^{42}$ Ibid., h. 126.

${ }^{43}$ Ibid., h. 126. 
sebagainya; yang terbagi atas (1) karena disengaja dan (2) karena kesalahan. Obyeknya bias: (1) mengenai bagian anggota tubuh manusia, (2) menghilangkan makna anggota tubuh, (3) luka di kepala, (4) luka pada anggota badan yang lain, dan (5)luka selain itu. Sedangkan hukumannya adalah qișaș, jika dimaafkan maka diganti diyah, dan jika dimaafkan maka diganti $t a{ }^{\prime} z i r$.

2. Dalam Hukum Pidana Indonesia, penganiayaan merupakan: (1) sengaja menyebabkan perasaan tidak enak (penderitaan), (2) menyebabkan rasa sakit, dan (3) menyebabkan luka; yang terdiri dari karena (1) kesengajaan atau (2) kealpaan. Terdapat lima macam, yaitu: (1) penganiayaan biasa (pasal 351 KUHP), (2) penganiayaan ringan (pasal 352 KUHP), penganiayaan biasa yang direncanakan lebih dahulu (pasal 353 KUHP), (4) penganiayaan berat (pasal 354 KUHP) dan (5) penganiayaan berat dengan direncanakan lebih dahulu (pasal 355 KUHP).

\section{Daftar Pustaka}

A. Djazuli. Fiqh Jinayah: Upaya Menanggulangi Kejahatan dalam Islam. Jakarta, Raja Grafindo. 1997.

Abd al-Qādir al-Audah. Al-Tashrī al-Jina’iy al-Islāmy Muqāran b al-Qānūn al-Waḍiy. Ttp.: Maktabah Dār al-Urubah, tt.

Ahmad Hanafi. Asas-asas Hukum Pidana Islam. Jakarta, Bulan Bintang, 2005.

Al-Mawardi. Prinsip-prinsip Penyelenggaraan Negara Islam. Terj. Fadhli Bahri. Jakarta, Darul Falah, 2000. Al-Shāfi'iy. Al-Umm, Jilid III. Beirut, Dār al-Fikr, tt. Moeljatno. KUHP (Kitab Undang-Undang Hukum Pidana). Jakarta, Bumi Aksara. 2007. 
Roeslan Saleh. Perbuatan Pidana dan Pertanggungjawab Pidana. Jakarta, Aksara Baru, 1983.

Samidjo. Pengantar Hukum Indonesia. Bandung, Armico, 1985.

Sudjari Dahlan. "Sudut Pandang Terhadap Rancangan KUHP”, dalam Makalah, Surabaya, 2001. 